\title{
Implementation of Green Infrastructure Principles in Dubrovnik, Croatia to Minimize Climate Change Problems
}

\author{
Ines Hrdalo \\ Dora Tomić \\ Petra Pereković
}

Ines Hrdalo, University of Zagreb, Faculty of Agriculture, Department of Ornamental Plants, Landscape Architecture and Historical Gardens, Croatia (ineshrdalo@yahoo.com)

Dora Tomić, University of Zagreb, Faculty of Agriculture, Department of Ornamental Plants, Landscape Architecture and Historical Gardens, Croatia (dtomic@agr.hr)

Petra Pereković, University of Zagreb, Faculty of Agriculture, Department of Ornamental Plants, Landscape

Architecture and Historical Gardens, Croatia (pperekovic@agr.hr)

\begin{abstract}
Increasing development pressure on the Croatian coastal zone has lead to environmental degradation due to a lack of appropriate strategies and policies in promoting well-planned and managed urban areas. Research has shown that six coastal cities have been facing problems connected with climate change (storm waters, floods, soil erosion and urban heath). Key elements of urban sustainability, in spatial context, are based on a balanced relationship between built and open urban spaces on one hand and connectivity between urban open spaces and between such spaces and surrounding landscapes at the regional scale (principles of urban green infrastructure). Detailed research based on comparative analysis shows that ecological problems have to do with unbalanced urban morphology in Dubrovnik (disappearance of green areas as absorptive surfaces and loss of connectivity). The findings offer a possible conceptual solution on applying the principles of green infrastructure, where the preservation and linkage of ecologically valuable green areas within urban fabric is crucial. These areas are planned as multifunctional spaces; they are important for biodiversity, urban morphology, and urban social life, as well as for mitigating the consequences of climate change.
\end{abstract}

Keywords: urban green infrastructure, sustainability, climate change, floods, Dubrovnik

\section{Introduction}

Due to global climate change, urban areas in dry and hot climate zones are especially vulnerable to its negative effects. In these conditions, a balanced relationship between green and grey surfaces is crucial for urban sustainability. The Croatian coastal zone has been under enormous development pressure over the past two decades. This has led to the development of urban centres with an unbalanced urban structure, tending to produce a higher percentage of grey zones with very fragmented green structures within the urban tissue. Problems occurred in a period of non-planned or strategically badly planned urban development, resulting in broad zones lacking planned green areas. These zones have been crucial in the development of problems connected with climate change.

\section{Background \\ Defining key themes}

Green infrastructure is a term that has recently gained increasing currency in the literature. But the background to this idea is much older and can be traced to notions of urban development over the last two centuries. When the nineteenth century city began to lose its shell (city walls) and to spread into the surrounding countryside, the close links of citydwellers with green surroundings (landscapes) began to disappear. Reconnection was 
therefore needed in the form of public parks. The systematicity of open spaces is apparent in a variety of urban planning and theoretical models of that period. The theme of continuity and green linkage of urban open spaces is, for instance, to be seen in Haussmann's plan for the city of Paris, in Wagner's plan for Vienna, in Olmstead's corridor parks, in Howard's model of "The Garden City", in Eberstadt, Möhring and Peterson's ideas for the development of Berlin (introduction of green wedges), as well as in a green belts and green finger plans from the mid-twentieth century (Hrdalo, 2013).

Today, green infrastructure is an emerging theme in EU politics which has incorporated this policy as a means of preserving valuable green areas outside and inside urban zones in the European Union Strategy 2020 (European Commission, 2013).

The Commission defines green infrastructure as a network of green spaces, habitats and ecosystems within a defined geographic area, which can range in size from an entire country to a neighbourhood and encompasses wild, semi-wild and developed environments (from wetlands to urban parks). Its functions range from providing ecosystem services to enhancing the human quality of life (European Commission, 2013).

But researchers have interpreted this term in different ways. Mell (2012) says that green infrastructure has been broadly defined in the literature to mean either investment in green space or as an infrastructure with sustainable objectives. While Vandermulen et al. (2011) have identified green infrastructure with green spaces in general, Roe and Mell (2013) define it as highly modified or engineered "intentional landscapes," not covered by spontaneous vegetation. Byrne et al. (2015) go beyond Roe and Mell in emphasising human modification and ecosystem services within green infrastructure (water purification, heat reduction), which are purposefully designed spaces. Beer (2010) adds that green infrastructure is purposeful, intentional, designed and destined primarily for widespread public use and benefit. An increasing awareness of its social importance has been traded by Byrne et al. (2015), Mell et. al. (2013), Mell (2013), Hrdalo (2013), Byrne (2011), Vandermulen et al. (2011), who highlight public usage and benefits. Byrne et al. (2015) and Hrdalo et al. (2015) therefore point to the socio ecological function of the green environment.

A number of studies identify the form of green infrastructure as an interconnected network of multifunctional spaces rather than solitary elements (or isolated private spaces), which are strategically planned and managed to provide a range of ecological, social and economic benefits (Mell, 2012.; Mathews et al., 2015; Benedict \& McMalan, 2006; Kanbites \& Owen, 2006; Tzoulas et al., 2007; Wright, 2011). Many authors define the elements of green infrastructure as public parks, public green spaces, greenways, green corridors, green roofs, green walls, permeable vegetated surfaces, green avenues and streets, urban forests, golf courses, community gardens, urban wetlands, biofilters and raingardens (Byrne and Yang, 2009; Douglas 2011; Foster et al., 2011; Gill et al., 2007; Klemm et al., 2015; Jim et al., 2015). Some consider all urban green elements to be part of the green infrastructure (Matthews, 2015), while others think that naturally occurred places are not to be included (Byrne et al., 2015).Gaffin et al. 2012, Lovell and Taylor, 2013, Newell et al. 2013 take the view that grey spaces with some green elements which can be habitats or have sustainable urban drainage systems can also be considered part of the green infrastructure. Some researchers debate whether even completely grey urban open spaces can participate in urban green infrastructure networks because of their social function, whose importance inside urban zones is emphasized (Hrdalo, 2013.).

Reviewing the definition of green infrastructure reveals some differences. Wright (2011) notes that different disciplines have attached different environmental, political, social and economic meanings to the concept, with little agreement as to how it should be defined and interpreted. As some studies have mentioned, local specific conceptualisations of green infrastructure are very important for its definition (Byrne et.al, 2015; Hrdalo et al, 2015). 
Climate change and the green infrastructure present new challenges for cities and their sustainability. Many authors have addressed problems of climate change and possible solutions involving the green infrastructure. Byrne et al. (2015) emphasize that green infrastructure has considerable potential to adopt cities to some emerging climate change impacts such as heat islands, increased flooding, higher wind speeds, and more episodic rainfall. These themes have been emphasized by many authors who stress the negative side effects of changes in climatic conditions (Brown et al., 2015; Demuzere et al., 2014; Gill et al., 2007; Byrne et al., 2015; Mathews et al., 2015; Byrne \& Young, 2009; Foo et al., 2015). Today the urban environment is reported to be under threat from many environmental problems: floods, storm waters, winds, and urban heat (Mathews et al., 2015; Brown et al., 2015; Demuzere et al., 2014; Beer, 2010; Bowler et al., 2010; Roy et al. 2012; Jim et. al., 2015) are having a negative impact on urban life. Many investigations have showed how green infrastructure can help reduce negative effects (Emamanuel \& Loconsdale, 2015; Bowler et al., 2010; Roy et al., 2012). Research in Glasgow noted that a $20 \%$ increase of green cover in urban areas could reduce the temperature by $2^{\circ} \mathrm{C}$ by 2050 (Emamanuel \& Loconsdale, 2015). Northon et. al. (2015) point out that the green infrastructure is becoming a more and more important aspect of spatial planning. The same issue is important for many other authors because climate change presents new challenges for green space planners and policymakers (Measham et al 2011; Perry, 2015; Byrne et al 2015; Byrne \& Yang, 2009; Foo et al., 2015; Pearson et al., 2015). Research in these field is very useful for areas with a Mediterranean and warm climate because of greater relative cooling benefits in hot and dry conditions (Otellé et al., 2011, cited in Norton et al., 2015).

\section{Methodology and working methods}

The specific hypothesis underlying our research is that urban green infrastructure can mitigate to climate change problems in non-planned or partially planned urban areas. A qualitative approach and two interlinked methodological approaches were adopted (Mathews et al., 2015): review of the scientific and specialised literature and spatial analysis of the urban footprint. Preliminary spatial analysis covered six Mediterranean coastal cities; Dubrovnik, Split, Šibenik, Zadar, Rijeka, and Pula, one town being selected for more detailed analysis. Dubrovnik was chose because it displays all the environmental problems addressed (and apparent in other places under study). The literature review was very important for understanding the relevant environmental issues relating to climate change.

The second step was to develop a digital database. Land use maps were collected and digitalized and an attribute database established. In the analytical phase, studies based on different inputs and guidelines (social, ecological, morphological) were undertaken. All spatial information was initially stored in AutoCAD georeferenced layers to maintain the consistency of coordinates and store data hierarchically. Different spatial informational layers were prepared in different ways for use in the spatial decision concept of the model. The AutoCAD database included layers, such as ecological, social and urban morphology

facilities. These layers were overlapped by the ecologically critical zones inside the urban area caused by climate change. Each layer was divided into components and re-structured to fit the decision concept model of green infrastructure.

\section{Case study: Dubrovnik}

Dubrovnik is located on the south Croatian coast and has a population of about 43. 000 . Surrounding areas basically depend on the town's facilities; it is a gravitation centre for more than 120.000 inhabitants of the region. The old town has been classified as an UNESCO world heritage site since 1979. The town's economy is based mainly on tourism. It is therefore under enormous development pressure. Non-strategic urban development has 
degraded the urban space and caused many environmental problems. The topography is characterised by hilly landscapes, with the areas most suitable for development being built up. The hill tops have accordingly preserved their natural greenery. The coast is preserved along the steep zones, especially cliff areas. Lately, many environmental problems connected with climate change have occurred. Storm waters have caused floods which disrupt normal urban life. Floods have to do with the deficiency of absorptive surfaces within the urban area (green zones). Green zones have been disappearing in a process of rapid and, from ecological point of view, unstrategic urban sprawl. At the same time, the loss of woodland (urban construction, fires) exacerbates soil erosion in steep areas within the urban zone (Topić et al., 2006). The loss of green zones and growth of grey zones has caused urban heat, very marked in hot and dry climates (Otellé et al., 2011, cited in Northon et al., 2015).

\section{Green spaces}

Green space within the perimeter of the town is highly fragmented. This is indicative of the deteriorating ecological value within the urban area. The development of the urban layout has changed dramatically over the past century, with green space fragmentation developing more intensively in recent years (Figures 1, 2, and 3). Hill slopes during twentieth century were covered with natural woodland and connected with urban green areas (parks, promenades). As these natural areas have disappeared, environmental problems have become more intensive. These natural green zones inside the urban perimeter are very important urban elements with high ecological value and potential for incorporation into public social life. At the same time, they are very important for urban morphology because from a human point of view they soften the city edges in vistas. They contribute to the visual complexity and balance the visual appearance of the urban tissue.

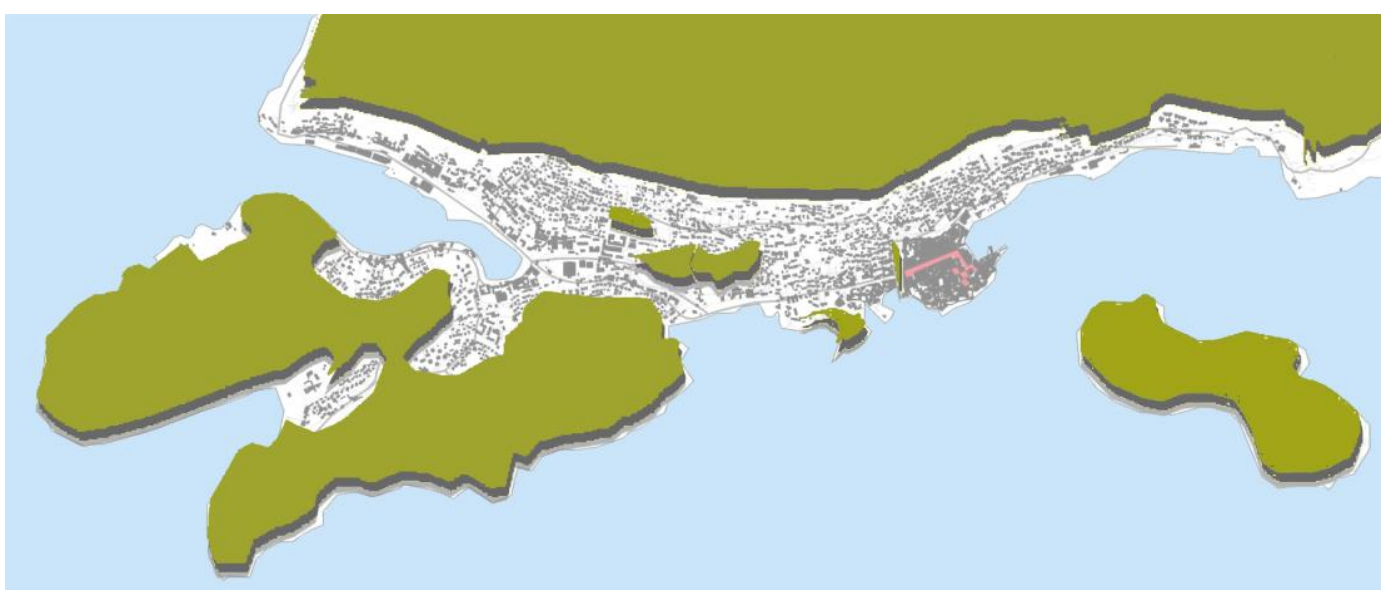

Figure 1: Green areas in Dubrovnik, 1910 (source: Hrdalo, 2013).

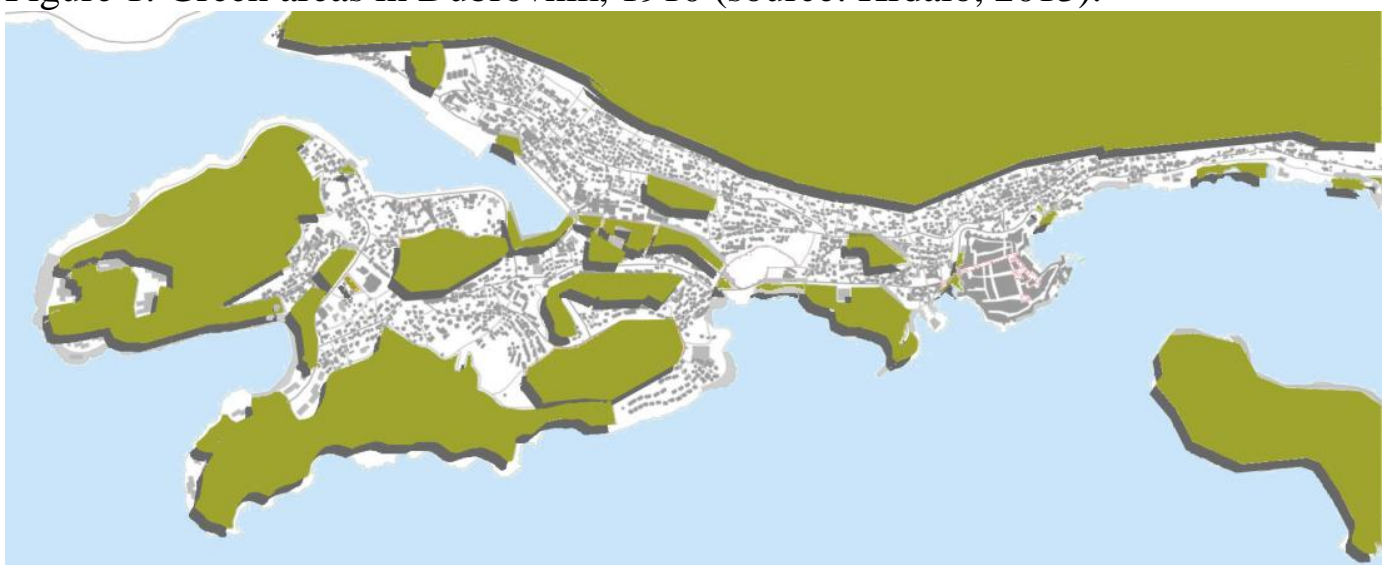

Figure 2: Green areas in Dubrovnik, 1988 (source: Hrdalo, 2013). 


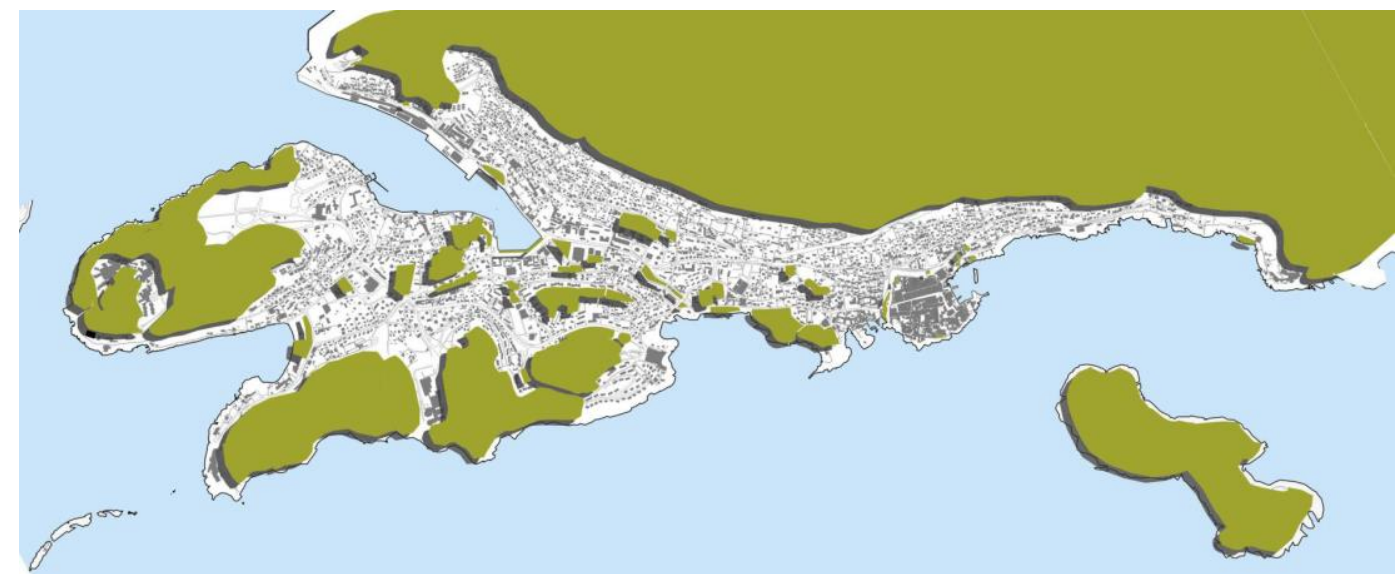

Figure 3: Green areas in Dubrovnik, 2003 (source: Hrdalo, 2013).

\section{Green areas and climate changes}

It is obvious that floods, soil erosion, urban heat, as side effects of climate change, can be linked with the reduction in green spaces in Dubrovnik. The disappearance of green areas within the urban perimeter entailed a reduction in absorptive surfaces for water. The lowest flat areas in Dubrovnik have therefore lately had problems with flooding. Many studies of karst relief in the Mediterranean climate zone have shown that soil erosion is a major problem on steep terrain (Topić et al., 2006.). Soil loss leads to problems in revitalising green zones and consequently implementing an urban green infrastructure policy. Solutions are urgently needed to prevent the exacerbation of environmental problems in the areas under study.

\section{Results}

The examination of six Mediterranean towns, Dubrovnik, Split, Šibenik, Zadar, Rijeka and Pula, has given us insight into environmental problems connected with climate change. Research has shown that storm water runoff and consequently floods and soil erosion, together with urban heat and winds are environmental problems that trouble the towns under study. In Dubrovnik all these problems are to be found; it was chosen therefore as a model to test possible solutions.

Structural analyses of the urban structure during the twentieth and twentieth first centuries have shown that the disappearance of green zones in urban areas has produced very unbalanced urban structures. At the beginning of the twentieth century, green areas covered more than $50 \%$ of the urban structure, while in the second half of the twentieth century the figure was about $50 \%$. Today's ground plan of the town shows more than $70 \%$ of the urban area to be predominantly grey. The problem was evidenced bythe number of green areas in the zone under study. While at the beginning of the twentieth century there were seven green areas there (with very high possible connectivity), in the second half of the century there were fifteen (with medium connectivity). In the twentieth first century there were more than thirty green areas (with medium connectivity). The size of green areas changed during twentieth and twent-first centuries. While at the beginning of the century $2 \mathrm{~km}^{2}$ of continuous green ground cover clad the hills within the urban perimeter, in the second half of the twentieth century and today all green surfaces (except Srđ hill which is at the border of the urban area) are smaller than $50000 \mathrm{~m}^{2}$ and more than $80 \%$ fragmented. Development of smaller and disconnected green urban units within the town area point to lower ecological potential and are closely associated with recent environmental problems. 
Map of ecologically problematic zones (Figure, 4). The data on which this map is based were collected from the literature and in field research. In this process problematic areas based on field research were mapped over a period of seven years, while older areas were mapped according to data from the literature and local newspapers. Flooding zones lie around Gruž bay and the level area of the old town where the lowest heights above sea level are measured. These zones flood frequently, over the past seven years regularly during heavy rains (at least once a year). These areas have becoming critical over recent decades since the green surfaces inside and around these areas have dramatically diminished (both areas are surrounded by steep slopes). The loss of absorptive ground and the development of predominantly grey surface have made these zones critical points with the urban perimeter. The second problematic issue addressed by the map of ecological problematic zones is urban temperature. This is given for the entire area under investigage, but is a bit more marked in zones grey than in green ones. This is very important issue in towns in dry and hot climate zones. A lower percentage of green areas within the urban perimeter correlates directly with higher temperatures, as Emanuel and Loconsdale (2015) have reported. At the same time, winter winds are causing problems (see map), which has to do with the loss of green cover (woodland) that can act as a buffer zone for a certain area, as mentioned by Brown et al (2015). In the ecologically problematic zones soil erosion is a problem, particularly on hill Srd, the highest elevantion, with very steep slopes, which is covered with lower karst vegetation, also referred to as macchia. Structural analyses have recognized it as an important element, partly inside the area under study, because of its roles of background to the urban area and connection with surrounding landscapes of high ecological value. Other ecological problems, such as pollution, lost of biodiversity were not addressed in this case study.

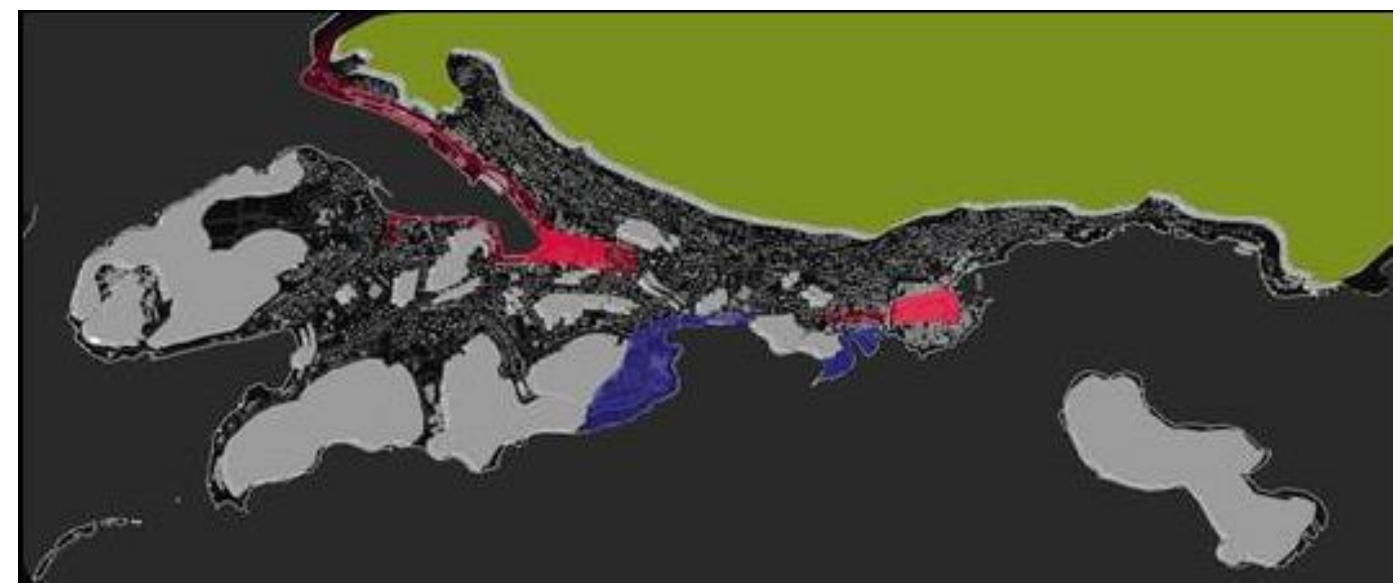

Figure 4: Map of ecologically problematic zones (red - flooding area, green - soil erosion, blue - strong winds).

\section{Urban green infrastructure development}

This analysis has provided a set of data used to develop a conceptual scheme of the urban green infrastructure in the quest for solutions to the problems discovered. The conceptual scheme indicates the main targeted areas within the area for preservation and the development of new green area connectivity. The purpose was to find solutions to green space fragmentation and the concomitant climate change-related problems. The focal point was the coastal line which could become a backbone of urban green infrastructure as it could connect $70 \%$ of the existing green areas. At the same time, the development of new landscape corridors and green lines to create ecological connections would surely enhance the ecological value of the town and mitigate climate change problems. The revitalisation of Srd hill, the highest elevation, can provide very important urban green infrastructure connections with the 
surrounding landscapes / with regional green infrastructure to establish ecological connectivity (European Commission, 2013). At the same time, flood prevention should include upstream catchment area within this zone. A higher percentage of green areas within the urban perimeter would mitigate urban heat by lowering temperatures (Emanuel \& Loconsdale, 2015). At the same time, green areas (vegetated zones) are an absorptive base and can absorb larger amounts of rain water (Topić et al., 2006). Implementation of bioretention and rain garden flooding problems can slow rain storm water and help solve flooding problems. These principles of urban green infrastructure have already been applied in other Mediterranean Croatian towns (for example Pula) with very good results (Uzelac, 2012).

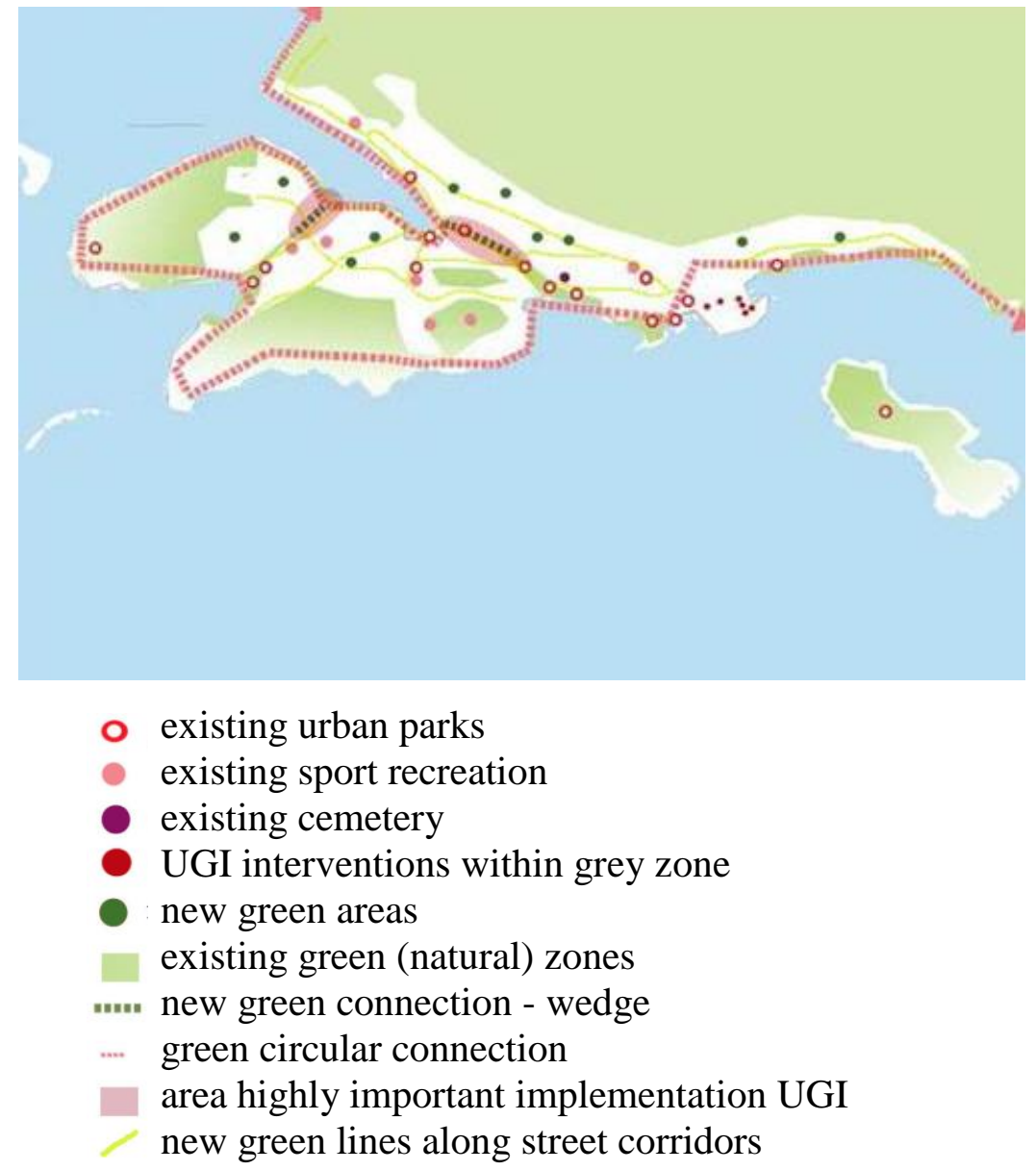

Figure 5: Conceptual scheme of urban green infrastructure.

\section{A framework for using Urban Green Infrastructure to mitigate climate change effects}

Analytical process has bought a set of collected data which were used for set of strategic framework. A five-step framework is proposed to prioritise urban public open space to satisfy the relevant principles. The framework is designed to operate firstly at the level of the entire town, then at the level of specific urban areas, neighbourhoods, and final at the street and micro-location levels. It is flexible and can be used and adapted for other urban areas with specific local conditions. Local stakeholders should be involved in the decision-making framework at any or all stages to represent the interests of the local community.

Step 1. Identifying the urban green infrastructure of the town as a whole

Urban green infrastructure, as a holistic approach to the urban area of Dubrovnik, has been identified as a concept of green infrastructure development that mitigates the dispersal 
structure of urban public open spaces. Connectivity between existing green cores inside the zones under study was established. Green wedges have been implemented within the urban tissue, especially along flooding zones (see the map of ecologically problematic zones), to connect urban green areas.

Step 2. Maximising the mitigation of climate change problems in existing green and grey areas

Existing green areas in Dubrovnik can implement green infrastructure principles very useful in mitigating climate change problems. Implementing sustainable urban drainage systems can help solve many environmental problems, primarily with flooding, such as those recently registered in the Dubrovnik. Grey structures can implement principles of sustainable urban drainage systems as well. As waterfront and public squares are nuclei of urban life in the Mediterranean town, they play a very important role in the social character of the urban green infrastructure (Hrdalo, 2013). Implementing the principles of urban green infrastructure in existing grey zones (open spaces) can reduce climate change problems (permeable pavement, collecting rain water, development of green roofs, green walls, and introducing dotted green elements). Bigger green zones in the area have big ecological and social potential. The implementation of urban green infrastructure principles and their integration in the social life of town is beneficial. The exact proportion of green areas and maximisation of their potential are very important factors. Since this involves questions of financial feasibility and investment, further investigation is needed, but this was not the focus of this investigation.

Step 3. Characterisation of priority zones in the new elements of the urban green infrastructure

Structural analyses and Map of ecologically problematic zones gave inputs for characterizing priority zones in development of new elements in conceptual scheme of urban green infrastructure (Figure, 5). These zones are connected to the flooding areas because it is a problem from ecological and social aspects. New wedges in a function of ecological corridor, which connects already existing green zones (with social functions), are linked to flooding zones that have been prioritized (as a result of this research).

Step 4. Developing the hierarchy of other new green spaces for the development of urban green infrastructure as socio-ecological concept

Other new green zones have been established and hierarchised in terms of vulnerability and ecological, social and visual potential, as well as possibilities and potential for easy implementation. New smaller green elements within the existing grey structure were accordingly proposed. Revitalisation of the highest and steepest elevation, Srd hill proposed as an element in urban development. In the long term, this would help mitigate climatechange problems by minimising soil erosion and providing a wind barrier for the urban area. At the same time, the development of a socio ecological zone within this area would contribute to developing social functions as well as to enhancing ecological values in Dubrovnik.

Step 5. Integration of urban green infrastructure on all scales

By developing the urban green infrastructure in different scales, the negative effects of climate change can be minimized. In this phase, the clear development of constraints and goals at higher levels and implementation at lower levels and scales are crucial for sustainability and flexibility. 


\section{Discussion and Conclusion}

Greater awareness of the negative impacts of climate change and of the possibilities of combating them has developed in recent years. Numerous studies have therefore focused on the problems caused by climate change and their impact on urban areas. As these problems have been emphasized in intensive built development, attention has been on the non-built environment, on green areas. It has been noted that these areas have mostly been developed as left-overs (between built zones) in urban zones; interest has focused on their potential for mitigating environmental problems. Intense storms, floods, soil erosion, strong winds, heat waves are all interconnected, and the role of the green infrastructure in their mitigation has been increasingly recognized (Byrne et al., 2015). Croatia has been a member of the European Union since 2013, and the recommendation of the European Commission (2013) to implement green infrastructure has aroused interest in urban and spatial planning institutions. However, it has not been easy to discover how to go about it. This was the background to the case study review of the potential offered by urban green infrastructure to counteract the impacts of climate. Many authors point to local specifics and the need to adapt urban green infrastructure principles, so that this process has to be very creative and local circumstances (natural and cultural) into account (Byrne et.al, 2015; Hrdalo, et al., 2015; Bowler et al., 2010). This required analysis of the urban space, causal relations, local characteristics, and specific ecological problems. The case study has proved useful because other towns under preliminary study showed similar problems. Dubrovnik displaying the whole range of climate-change related problems (noted in one or other or the other sites under study), the findings of this case study can prove useful and the methodology applicable for other towns. The research shows that spatial analysis can be a very useful tool for understanding urban structures, and collation with other thematic maps it can provide many useful (for example ecological) data. The results also suggest that identifying problems and their causes is very important step towards understanding the situation and finding solutions. The findings could show how planners can frame the problems of climate change and adaptive responses. Recognizing the benefits of the urban green infrastructure is an important of stage in developing the spatial potential for mitigating climate-change problems. Analysiss of the Dubrovnik urban area shows that climate-change problems have have manifested themselves more strongly in recent years since high the space within the urban perimeter has become predominantly grey. This study suggests that the rapid development of built areas has worsened the situation, because flooding (which can be considered the worst climate change problem) has been more frequent over the last few years. This can be attributed to the loss of many absorptive surfaces (green surface) in the process of intensive construction. This research has therefore focused on identifying critical areas in the study area (map of ecologically problematic zones). The development of solutions in the form of a conceptual scheme of urban green infrastructure has been an important outcome of this investigation. In the form of a map it offers an integral urban plan based on a holistic approach. The regional context was crucial in developing this layout, so that connections with surrounding landscapes have been considered a key factor of urban sustainability. Such a conceptual scheme naturally has certain limitations; a more detailed and programmed database is required to take it further. Developing a framework for using the urban green infrastructure to mitigate the effects of climate change has been considered a tool for the easier application of this infrastructure (Norton et al., 2015). Planners should be aware of the different scales and layers in which the infrastructure can be applicable. A five stage framework can be more easily followed and adapted to local situations, capacities, and circumstances by practitioners. This framework can be helpful in setting priorities for the implementation of urban green infrastructure measures in urban public open spaces applying the relevant principles, notably in critical zones but also in the city as a whole. 
Urban green infrastructure should be an important component in urban planning because of its multifunctionality in terms of benefits to community, to ecosystems and to urban morphology (which is emphasized in the field of landscape urbanism; Waldheim, 2006). As every town has its own local conditions and situations, flexibility with regard to urban green infrastructure is crucial. This study presents, justifies and applies a model for the application of urban green infrastructure but with certain limitations. A great deal of work needs to be done in in identifiying new meanings and possibilities for urban green infrastructure in every new situation and location. Nevertheless, there is sufficient information and data for municipalities to tackle the negative effects of climate change by applying urban green infrastructure principles.

The City of Dubrovnik has taken first steps towards developing the urban green infrastructure through the framework to which the authors have contributed.

\section{References}

Beer, A. R. (2010) Green spaces, green structure, and green infrastructure planning. Urban ecosystem ecology, pp. 431-448 DOI:10.2134/agronmonogr55.c21

Bendict, M. A. \& McMahon, E. T. (2006). Green infrastructure: Linking landscapes and communities. Washington, DC, Island Press.

Byrne, J., \& Yang, J. (2009). Can urban green space combat climate change? Towards a subtropical cities research agenda. Australian Planner, 46, pp. 36-43.

DOI:10.1080/07293682.2009.10753420

Byrne, J. (2011). The human relationship with nature: Rights of animals and plants in the urban context. In: Douglas, I., Goode, D., Houck, M. C., \& Wand, R. (eds.) The Routledge handbook of urban ecology, pp. 63-73. New York, Routledge.

Byrne, J. A., Lo, A. Y., \& Yang, J. J. (2015) Residents' understanding of the role of green infrastructure for climate change adaptation in Hangzhou, China. Landscape and Urban Planning, 138, pp. 132-143. DOI:10.1016/j.landurbplan.2015.02.013

Bowler, D. E., Buyung-Ali, L., Knight, T. M., \& Pullin, A. S. (2010) Urban greening to cool towns and cities: A systematic review of the empirical evidence. Landscape and Urban Planning, 97(3), pp. 147-155. DOI:10.1016/j.landurbplan.2010.05.006

Brown, R., Vanos, J. K., Kenny, N. A., \& Lenzholzer, S. (2015) Designing urban parks that ameliorate the effects of climate change. Landscape and Urban Planning, 138, pp. 118131. DOI:10.1016/j.landurbplan.2015.02.006

Demuzere, M., Orru, K., Heidrich, O., Olazabal, E., Geneletti, D., Orru, H., et al. (2014) Mitigating and adapting to climate change: Multi-functional and multi-scale assessment of green urban infrastructure. Journal of Environmental Management, 146, pp. 107-115. DOI:10.1016/j.jenvman.2014.07.025

Douglas, I. (2011) The role of green infrastructure in adapting cities to climate change. In: Douglas, I., Goode, D. \& Houck, M. (eds.) Handbook of urban ecology. Florence, KY, Routledge.

Emmanuel, R. \& Loconsole, A. (2015) Green infrastructure as an adaptation approach to tackle urban overheating in the Glasgow Clyde Valley Region,UK. Landscape and Urban Planning, 138, pp. 71-86. DOI:10.1016/j.landurbplan.2015.02.012

European commission (2013) European Parliament resolution of 12 December 2013 on Green Infrastructure - Enhancing Europe's Natural Capital. Available at: http://ec.europa.eu/environment/nature/ecosystems/index_en.htm (accessed 20 May. 2015).

Foo, K. E., McCarthy, J., \& Bebbington, A. (2015) A framework for governing urban green infrastructure. Landscape and Urban Planning, 138, pp. 40-51. 
Foster, J., Lowe, A. \& Winkelman, S. (2011) The value of green infrastructure for urban climate adaptation. Washington, DC, Centre for Clean Air Policy.

Gaffin, S. R., Rosenzweig, C. \& Kong, A. Y. Y. (2012) Adapting to climate change through urban green infrastructure. Nature Climate Change, 2(10), pp. 704.

Gill, S. E., Handley, J. F., Ennos, A. R. \& Pauleit, S. (2007) Adapting cities for climate change: The role of the green infrastructure. Built Environment, 33, pp. 115-133. DOI: 10.2148/benv.33.1.115

Hrdalo, I. (2013) Green systems in the evolution of the open space of selected Mediterranean towns. Doctorial dissertation. Ljubljana, Biotechnical University.

Hrdalo, I., Pereković, P., Tomić, D. (2015) Opportunities and Constraints for Implementation of Green Infrastructure Network - The Research on Mediterranean Historical Towns in Croatia. Eclas conference proceedings.

Jim C.Y., Lo, A. Y., Byrne J.A. (2015) Charting the green and climate-adaptive city, editorial. Landscape and Urban Planning, 138, pp. 51-53.

Kambites, C. \& Owen, S. (2006) Renewed prospects for green infrastructure planning in the UK. Planning, Practice \& Research, 21(4), pp. 483-496. DOI: 10.1080/02697450601173413

Klemm, W., Heusinkveld, B. G., Lenzholzer, S. \& Van Hove, B. (2015) Street greenery and its physical and psychological impact on outdoor thermal comfort. Landscape and Urban Planning, 138, pp. 87-98. DOI: 10.1016/j.landurbplan.2015.02.009

Lovell, S. T. \& Taylor, J. R. (2013) Supplying urban ecosystem services through multifunctional green infrastructure in the United States. Landscape Ecology, 28(8), pp. 1447-1463. DOI: 10.1007/s10980-013-9912-y

Matthews, T., Lo, A. Y. \& Byrne, J. (2015) Reconceptualising green infrastructure for climate change adaptation: Barriers to adoption and drivers for uptake by spatial planners.

Landscape and Urban Planning, 138, pp. 155-163. DOI: 10.1016/j.landurbplan.2015.02.010

Mell, I. C. (2012) Can you tell a green field from a cold steel rail? Examining the green of green infrastructure development. Local Environment, 18(2), pp.152-166. DOI:

10.1080/13549839.2012.719019

Mell, I. C., Henneberry, J., Hehl-Lange, S. \& Keskin, B. (2013) Promoting urban greening: Valuing the development of green infrastructure investments in the urban core of Manchester, UK. Urban Forestry \& Urban Greening, 12, pp. 296-306. DOI: 10.1016/j.ufug.2013.04.006

Mell, I. C. (2013) Can you tell a green field from a cold steel rail? Examining the ,green” of Green Infrastructure development. Local Environment, 18, pp. 152-166.

Measham, T. G., Preston, B. L., Smith, T. F., Brooke, C., Gorddard, R., Withycombe,G., et al. (2011) Adapting to climate change through local municipal planning: Barriers and challenge. Mitigation and Adaptation Strategies for Global Change, 16 (8), pp. 889-909. DOI: $10.1007 / \mathrm{s} 11027-011-9301-2$

Newell, J. P., Seymour, M., Yee, T., Renteria, J., Longcore, T., Wolch, J. R., et al. (2013) Green Alley Programs: Planning for a sustainable urban infrastructure? Cities, 31, pp. 144-155. DOI: 10.1016/j.cities.2012.07.004

Norton, B. A., Coutts, A. M., Livesley, S. J., Harris, R. J., Hunter, A. M. \& Williams, N. S.G. (2015) Planning for cooler cities: A framework to prioritise green infrastructure to mitigate high temperatures in urban landscapes. Landscape and Urban Planning, 134, pp. 127-138. DOI: 10.1016/j.landurbplan.2014.10.018

Pearson, L. J., MacKenzsie, A. \& Pearson, C. J. (2015) A tale from two cities: Frame-work to support green infrastructure planning. Landscape and Urban Planning, 138, pp. 30-40. 
Perry, J. (2015) Climate change adaptation in the world's best places: A wicked problem in need of immediate attention. Landscape and Urban Planning, 133, pp. 1-11. DOI: 10.1016/j.landurbplan.2014.08.013

Roe, M. \& Mell, I. (2013) Negotiating value and priorities: Evaluating the demands of green infrastructure development. Journal of Environmental Planning and Management, 56(5), pp. 650-673. DOI: 10.1080/09640568.2012.693454

Roy, S., Byrne, J., \& Pickering, C. (2012) A systematic quantitative review of urban tree benefits, costs, and assessment methods across cities in different climatic zones. Urban Forestry \& Urban Greening, 11(4), pp. 351-363. DOI: 10.1016/j.ufug.2012.06.006

Topić, V. Butorac, L., Jelić, G. (2006) Površinsko otjecanje padalina i erozija tla u šumskim ekosustavima alepskog bora. Radovi šumarskog instituta, 9, pp. 127-137.

Tzoulas, K., Korpela, K., Venn, S., Yli-Pelkonen, V., Ka'zmierczak, A., Niemela, J.,et al. (2007) Promoting ecosystem and human health in urban areas using green infrastructure: A literature review. Landscape and Urban Planning, 81(3), pp.167-178. DOI: 10.1016/j.landurbplan.2007.02.001

Uzelac, T. (2012) Integralni pristup odvodnji površinskih i oborinskih voda. Hafencity Universitat Hamburg, Hamburg

Vandermeulen V., Verpecht A., Vermire B., Van Huylenbroeck G., Gellynck X. (2011) The use of economic valuation to create public support for green infrastructure investments in urban areas. Landscape and urban planning, 103 (2), pp. 198-206. DOI: 10.1016/j.landurbplan.2011.07.010

Waldheim, C. (2006) The landscape urbanism reader. New York, Princeton Architectural Press.

Wright, H. (2011) Understanding green infrastructure: The development of a con-tested concept in England. Local Environment, 16, pp. 1003-1019. 